\title{
Breaking the Chain of Silence: Political Activism and Social Justice in Omar Offendum's Syrian-American Hip-Hop
}

\author{
Harry Olafsen ${ }^{a}$, Mohammed Ali, Mikayla McCord ${ }^{*}$, Dr. Roxana Cazan * \\ ${ }^{a}$ Department of Literature and Languages, Saint Francis University, $P A$ \\ ${ }^{b}$ Pre-Medicine Track, Indiana University of Pennsylvania, $P A$ \\ ${ }^{c}$ College of Arts and Sciences, University of South Carolina in Columbia, SC
}

Mentor:RCazan@francis.edu*

\begin{abstract}
Dissatisfied with the decisions of the Western political class to remain uninvolved in helping settle the conflict in Syria, many hiphop, rap, and pop artists from Syria and the surrounding region have been creating and performing politically charged music that promotes liberty, and justice in the Middle East. One artist in particular, Omar Offendum (in the United States), writes and brings to the stage his hip-hop music in a way that continues and enhances this political-artistic movement across the Atlantic. Employing rhymes and rhythms that foster commotion and make noise, Offendum breaks the global indifference accumulated around the topics of the Syrian war and the unsolvable debates about allowing a certain number of Syrian asylum seekers to apply for refugee status in Western nations. He underscores that apathy is not an option for those who oppose the oppressor. In this paper, we argue that Offendum's music constitutes an effective tool of political propaganda that can raise social consciousness of the needs of Syrians today and inspire social justice. Because the political-ideological space that feeds his creative act is set in a civil-rights-conscious U.S., Offendum often appeals to a heritage, reminding the listener of the activism of the Black Panthers, the legacy of Malcom X, and the freedom battles of Rodney King and his followers. In many of his songs, Offendum uses Arabic, both as a means of highlighting the authenticity of his hybrid identity and as a method of marking a cultural space for a diverse audience to come together. In this paper, we offer a brief historical look at the role of hip-hop in the struggle for civil rights in the US in order to locate the legacy Offendum's music builds on and to assess its power. We then perform a close analysis of three of his most famous songs and conclude with a brief discussion of the impact of Offendum's on social media platforms globally.
\end{abstract}

\section{KEYWORDS}

Hip-Hop; Activism; Social Justice; Omar Offendum; Social Consciousness; Syrian War; Syrian Refugees; Civil Rights

\section{INTRODUCTION}

When the world witnessed Mohamed Bouazizi's self-immolation as a means of protesting against a regime whose lack of transparency and violent rulings had stopped representing the Tunisian people, few could have predicted the ways in which the series of revolutions that mark the recent history of the Middle East, known as the "Arab Spring", would unfold. ${ }^{1}$ Only a few months later in Syria, a group of students who painted anti-government graffiti slogans in the city of Daraa were caught and tortured by government forces. ${ }^{1}$ As civil unrest ensued, the Syrian government led by President Bashar Al-Assad pushed to promote the notion that the Syrian unrest had been, in fact, created by foreign conspiracies and by sectarian disputes. ${ }^{2}$ As the Syrian revolt crystalized into a civil war that ran entire cities into ruin, waves of displaced people were driven out of their homes, their towns, and even their own country, so much so that eleven million Syrians have abandoned their homes since $2011 .{ }^{3}$ The situation has been aggravated by the terrorist actions of Da'esh, ${ }^{a}$ a militant group that calls itself Islamic and controls much of Syria's oil assets in the east of the country. Sadly, the crisis shows no signs of resolution in Syria and elsewhere in the Middle East, with the Turkish coup attempt of July 15, 2016 indicating that other regimes continue to fail in serving the needs of their citizens. ${ }^{4}$ Perhaps "fearful of offending the pro-Assad Iranian government with which he [negotiated] a nuclear arms deal," United States President Barack Obama and others like him, including for instance, Germany's Chancellor Angela Merkel, have failed to take systematic action to alleviate the conflict. ${ }^{5}$

Dissatisfied with the decision of the Western political class—a group of elites who control most of the wealth and power across the world— to remain uninvolved, many hip-hop, rap, and pop artists from Syria and the surrounding region have been producing a kind of music that has received global attention for promoting equality, liberty, and justice in the Middle East. Among these performers are Kurdish Iranian Helan Adbullah known on stage as Helly Luv, Syrian group Syrian Hip Hop Unity, or Syrian solo artists Amer Akka, Abdul Rahman Masri, and Mohammad Abu Hajar who live and perform as refugees in European countries. Their performances aim to raise awareness about the Syrian Civil War, the destruction caused by Da'esh, the greed of politicians to the detriment of every-day citizens, the civilian casualties of a war that seems to kill women, children, and the elderly first, or the lack of efficient involvement from Middle Eastern state coalitions, Islamic brotherhood groups, and Western alliances. These 
artists generally record songs in Arabic and film low budget videos that circulate on social media platforms, accompanied by English subtitles, in order to captivate a mixed audience and to bridge the East and the West. Their employment of Western music genres, often merging traditional Arabic melodies, indicates that their ideological intent politicizes music production by placing an emphasis on North American-born activism through protest, performance, and consumption. Although he lives and works in the United States, one artist in particular, Omar Offendum, creates and performs music from the U.S. in a way that continues and enhances this political-artistic movement across the Atlantic.

Syrian-American hip-hop performer, Offendum uses music and poetry to speak out against the violence in Syria. According to the biographical notes listed on his website, ${ }^{6}$ Offendum was born in Saudi Arabia, but moved to the United States at the age of four. As an artist, Offendum calls Los Angeles his home, a space that allows him to record and distribute both his music and his political activism. Much of Offendum's music and verse stem from a deep feeling of guilt for having had the privilege of a much quieter destiny than his brothers and sisters in Syria. In fact, this is visible in his choice of name: Offendum is derived from the English verb "to offend" and from the Arabic word for "Sir," and aims to unsettle the listeners' assumptions and stereotypical representations of Middle Easterners in the Western world. In a sense, Offendum's ideas oppose a particular political view in the U.S., a view that has been reenergized by the President of the United States, Donald Trump and his xenophobic attitudes towards immigrants, and Muslims in particular. Employing rhymes and rhythms that foster commotion and make noise, Offendum breaks the global silence accumulated around the topic of the Syrian war and argues that apathy is not an option for those who oppose the oppressor. Offendum's music constitutes an effective tool of political propaganda that can raise social consciousness of the needs of Syrians today, allow Syrians self-determination, and afford Syrian-Americans equal participation in a society modeled to meet their needs through "cooperation between citizens regarded as free and equal." In this paper, we argue that Offendum combines rhetorical, linguistic, and musical choices from his Syrian background with arguments referencing the U.S. civil rights movement in a way that energizes groups of young Western hip-hop listeners, in order to educate his audiences about the current Syrian conflict.

A careful analysis of his lyrics shows that Offendum aims to accomplish several goals with his music. First, he raises awareness about the state of war in Syria, Syria's extremely diverse citizenry, and its rich culture. Second, the performer's music moves the masses into action_-both physically and an ideologically_ as they consider the fate of Syrian refugees in the world today and the unearned privileges others get to experience. Third, Offendum encourages Syrian refugees and immigrants to take an active role in reforming the future for the sake of the next generations. Because the political-ideological space that feeds his creative act is set in a civil-rights-conscious United States, Offendum often appeals to a heritage, reminding the listener of the activism role of the Black Panthers, the legacy of Malcom X, and the freedom struggle of Rodney King. In many of his songs, Offendum uses Arabic, both as a means of creating cultural authenticity and as a method of delineating a cultural space for a diverse audience to come together. We offer a brief historical look at the role of hip-hop in the struggle for civil rights in the U.S. in order to contextualize the power and legacy of Offendum's music. We then perform a close analysis of three of his most famous songs about Syria and conclude with a brief discussion of the impact Offendum's music has on social media platforms globally.

\section{HIP-HOP HISTORY, POLITICAL ACTIVISM, AND THE ARAB SPRING}

In recent years, many debates have been led on whether hip-hop as a phenomenon is culturally enhancing or degrading. For instance, performers and producers such as Jesse Jackson, KRS-One, Q-Tip, Estelle, P. J. O'Rourke, Jaron Lanier, as well as poets and scholars joined a talk show moderated by BBC host Emily Maitlis in June of 2012 to determine the cultural value of this genre. ${ }^{8}$ In his article "From Civil Rights to Hip Hop: Toward a Nexus of Ideas," intellectual historian Derrick P. Alridge argues that socially and politically conscious hip-hop continues an ideology solidified by the Civil Rights Movement and the Black Freedom Struggle. ' Echoing Alridge's claim, in her book The Cultural Politics of Slam: Race, Identity, and the Performance of Popular Verse in America, Susan Somers-Willet compares hip-hop to spoken word poetry, but underlines that despite their similar ideological concerns, the first genre is solely driven by its commercial goals while the second is not. ${ }^{10 \mathrm{~b}}$ Somers-Willet argues that spoken word poetry, a genre concerned with creating a discursive poetic space for speakers whose identities have been historically and systematically pushed to the margins or erased, opposes the gangster rap phenomenon that emerged in the aftermath of Rodney King's trial in 1991.10 While gangster rap celebrates "black criminality, promiscuity, misogyny, drug use, and ghetto violence," spoken word poetry and non-commercial hip-hop are concerned with declaring marginalized identities, praising their authenticity, and speaking against prejudice. ${ }^{10}$

To really understand the significance of hip-hop's cultural value, one must take a closer look at the emergence of hip-hop and the civil rights agendas that hip-hop aimed to underscore. Hip-hop was born in 1973 in an apartment in one of New York's poorest neighborhoods - the Bronx — when 18 year-old, Jamaican-born Clive Campbell (more commonly known as Kool DJ Herc) decided to do something new on the turntable. While entertaining his younger sister's back-to-school party, he began to extend the beat of the records by "breaking" them or using two turntables to meld popular dance songs with percussion tracks. His goal was simply to liven up the party's atmosphere, but what developed was a lasting trend that became the root of the new genre: hip- 
hop.11, 12 DJ Herc's style did not simply offer a different kind of music, but it also produced a new way of thinking about inner-city life. For example, hip-hop inspired American DJ Afrika Bambaataa to found an organization called the Zulu Nation in November 1976, which aimed to promote an awareness about the consequences of gang violence in the Bronx and to end it. ${ }^{12}$ What started out as a trend in New York City's shabbier neighborhoods gained worldwide eminence with the release of The Sugarhill Gang's song "Rapper's Delight" in 1979.11

The golden age of hip-hop began in the mid-eighties and lasted until the early nineties with the introduction of rock style hip-hop which later became more influenced by jazz, soul, R\&B, reggae, and newer audio-editing technology. During the 1980 s, the popularity of hip-hop music at parties coupled with the emergence of breakdancers and graffiti artists gave rise to a culture of hiphop that never previously existed, primarily embraced by African American youth. ${ }^{11}$ This era is notable because many of the singers began to focus their attention more consistently on addressing social and political issues. For instance, when he created Do the Right Thing featuring Public Enemy's now famous anthem "Fight the Power," in 1989, director Spike Lee set to portray the boiling big-city racial tensions. In a Rolling Stone interview Hank Shocklee commented on the civil rights value of this song:

It was Public Enemy's and Spike Lee's defining moment because what ["Fight the Power"] had done was it had awoken the black community to a revolution that was akin to the Sixties revolution, where you had Martin Luther King or Malcolm X. It created such an energy surge throughout the community that it became the template for every artist, every filmmaker, every rapper, singer, and it also sparked community leaders and teachers to understand the power of hiphop. ${ }^{13}$

If scholars like Dave Ramsaran and Simona Jill locate the beginning of hip-hop culture in the 1980 s, ${ }^{14}$ others argue that in the following decade, this culture diversified greatly. For example, fueled by the court injustice done to Rodney King, two specific styles of hip-hop developed in the nineties: the rap of New York and the G-Funk of Los Angeles. ${ }^{15}$ Many groups continued the trend of using hip-hop for social change. For example, when the members of the musical group NWA first started to perform in their home neighborhood, Compton, one of LA's poorest and most violent districts, they rapped about the injustice and police violence in their neighborhood. ${ }^{16}$ These hip-hop styles were notably different than earlier styles, as they began to incorporate more profanity and depictions of drug-use, sex, and misogyny. However, the turn of the twenty first century hailed a new stage of hip-hop music that is a lot less rigid in its definition of the genre and is characterized primarily by its diversity and constant evolution. ${ }^{17}$ For instance, singers like Jay Z, Eminem, and Kanye West have all been attributed with revolutionizing the genre within the last decade and broadening its depth.

Many scholars have commented on the potential for equal rights activism that hip-hop displays. For example, Adam Haupt explains the ways in which black hip-hop artists used sampling — a type of music collage — as a subversive way to seize the normative, white-centered means of production and appropriation. ${ }^{18}$ Todd Boyd also stresses the inherently political nature of hip-hop. ${ }^{19}$ The civil rights movement was propelled primarily by the force of music that unified and inspired chiefly by combining gospel music, Negro spirituals, and blues. ${ }^{20}$ The power of this unique combination was that it gave a feeling of historical continuity while simultaneously hailing evolution. This genre imagined that each individual was strong and that as a group, the performers were united in a struggle that transcended boundaries and even generations. For example, the song "Walk Together Children" encouraged young black men and women to march toward freedom with unyielding perseverance. ${ }^{21}$

In many ways, hip-hop picked up where these "freedom songs" left off. Hip-hop is frequently described as a weapon that pierces the mind and forces one to think by removing all barriers to the truth. For instance, African, African American, and Caribbean Studies professor, Reiland Rabaka, argues that despite some controversy, golden age rap, that touts African American insurgent organizations or activists (the Black Panther Party, Malcom X, Nation of Islam, and others),

reinvigorate $[\mathrm{s}]$ black historicism and black cultural consciousness enables black youth-who, without one word of hyperbole, as late as the close of the first decade of the twenty-first century, have little or no access to authentic African American studies (as opposed to Eurocentric African American studies) — to comprehend and connect the conditions of the past with the parlous circumstances of their present, archeologically and aesthetically utilizing the past as a seminal source for cultural creation, social reflection, political resistance, and movement rallying in the present. ${ }^{22}$

By echoing the political ideologies of past activists, hip-hop artists were able to extend their influence and preserve their memory. For instance, Beyonce's R\&B/hip-hop song entitled "Freedom" and featuring Kendrick Lamar focuses on denouncing police brutality in an effort to demilitarize officers; this will give people of color, who are disproportionately impacted by police violence, access to freedom. 
In the song, Lamar raps:

Eight blocks left, death is around the corner.

Seven misleadin' statements 'bout my persona.

Six headlights waivin' in my direction.

Five-O askin' me what's in my possession.

This sequence reflects some of the recent fatal attacks on the African American community by some police officers. In this way, rap songs, such as "Freedom," push the narrative arguing that social change continues to be an important goal and mirror the ideologies of both Martin Luther King Jr. and Malcom X.

Hip-hop's influence is not felt only by Americans but by the international community at large. For example, post-apartheid South Africa has developed kwaito, a homegrown style of music which is similar to hip-hop and used to heighten and honor black pride. ${ }^{23}$ Likewise, in Cuba "el rap" is used to highlight government corruption and unfair discrimination against black Cubans. ${ }^{23}$ Additionally, in Rio de Janeiro, impoverished children are being encouraged by former drug dealers who have reformed their lives to become involved in the production of hip-hop as opposed to getting involved in the drug trade. ${ }^{23}$ Even half-way across the globe, hip-hop is being lauded by the younger generation in Japan and is helping to spread diversity and cultural acceptance.23 What makes hip-hop so powerful is the force that characterizes it. Hip-hop activism has been used worldwide to stand up for social issues, from environmental racism to global poverty and police brutality.

The most celebrated themes in American hip-hop are the need for "freedom" and "opportunity" for minority groups who have been historically excluded from political life and civil rights. However, a new type of hip-hop today asks audiences to reconsider the targeted group and highlights that throughout history, such privileges have been refused also for immigrants and refugees to the U.S. This new type of hip-hop reminds the listener that at almost every crucial point in recent history America has failed to open its door and heart to refugees, whether they were Jews after WWII, Vietnamese in the 1970s, Cubans in the 1980s, Haitians in the 1990s, or most recently Mexicans and Syrians. ${ }^{c}$ Considering the antipathy directed against the Syrian refugee crisis that represents a concern for many liberal individuals and groups in the U.S., it is no surprise that as of May 24, 2016, the U.S. had admitted merely 2,540 Syrian refugees since the civil war began five years earlier, (although today, the U.S. has met its 10,000 quota). ${ }^{24}$ This lag in response is unsurprising when considering the barrage of racist and Islamophobic vitriol that rose up again in the months following the November 2015 Paris attacks. Islamophobia in the U.S. is not new. Moustafa Bayoumi, associate professor of English at Brooklyn College, follows W. E. B. Du Bois's argument that African Americans constituted a "problem" particularly at the height of the Jim Crow, when segregation practically dehumanized African Americans to the rest of the world. Bayoumi contends that "since the terrorist attacks of September 11 and the wars in Afghanistan and Iraq, Arabs and Muslims, two groups virtually unknown to most Americans prior to 2001, now hold the dubious distinction of being the first new communities of suspicion after the hard-won victories of the civil-rights era." 25 Leaders of the Republican Party have called for both the registering and branding of Muslims labeling of Syrian refugees as "rabid dogs." 26 Roanoke's mayor has gone so far to suggest that internment camps for Muslims would be a viable and acceptable solution in containing terrorism. ${ }^{27}$

While it is fairly known that politically-charged hip-hop has recently become the soundtrack for pro-democracy movements of the Arab Spring phenomenon across the Middle East, ${ }^{\mathbf{d}}$ few discussions arise around the function of American hip-hop in articulating ideologies of peace for Muslims in the world. For example, Palestinian artists create hip-hop in an attempt to re-construct, preserve, and assert their identity in the face of Israeli oppression. ${ }^{28}$ Drawing from urban African American hip-hop, Palestinian performers re-appropriate black culture, which they see as a global culture "transferrable to various marginalized and oppressed cultures and ethnicities." 28 Attention should be paid to the Arab-American hip-hop interventions as alternative ways of identity formation and the crystallization of a collective consciousness. Such performers underscore their hyphenated identities as spaces of cultural hybridity, allowing them to "resist being defined by others." 28 The artistic expression of this hybridity rests in their combination of English and Arabic verses, the music sampling of traditional Arab melodies, or the insertion of lines of famous Arabic poetry, (e.g. the activist work of Nizar Kabbani and Mahmoud Darwish). Ethnomusicologist Mark Slobin explains that in this way, Arab American artists connect both locales (home and abroad, wherever they may be) and many generations in ways that allow them to bridge the past and the present. "They rap about checkpoints, military oppression and refugee camps. Their songs express longing for Jerusalem and anger at the hardships of life in the Gaza Strip and West Bank."29

\section{OMAR OFFENDUM'S HIP-HOP}

Offendum uses his Syrian heritage to his advantage by showing versatility in both Arabic and English. Offendum can get his message across to more people, Western and Eastern alike, by rapping in both English and Arabic. His bilingual lyrics also illustrate a symbolic means of existing in the world as a first or second generation immigrant, whose identity is hyphenated. In the U.S., his Syrian identity often conjures negative connotations, invoking stereotypical association with terrorism, particularly after 
September $11^{\text {th }}$. Associate professor of sociology at Colorado State University, Lori Peek reflects extensively on Muslim discrimination, describing in her book, Behind the Backlash: Muslim Americans after 9/11, that a multitude of self-proclaimed experts on terrorism came out after $9 / 11$ to offer harmful overgeneralizations of Muslims as paragons of evil to an already terrified civil society. Peek offers the strategic example of Evangelical Christian leader, Franklin Graham, who delivered the sermon at President Bush's inauguration and who declared that Islam is an evil religion. ${ }^{30}$ These attitudes have not only persisted, but were aggravated recently. Since November the average number of hate crimes against Muslims in the U.S. has more that tripled from 12.6 to over 38 a month. ${ }^{31}$ The noose seems to be tightening for American Muslims and Syrian refugees, and they are left with nowhere to turn to for relief and reprieve. By weaving Arabic with English throughout his music, Offendum forces his audiences to confront their stereotypical assumptions, set them aside, and lend an ear.

As a Syrian-American, Offendum utilizes an interesting fusion of mainstream hip-hop with Arabic poetry. By doing so he also infuses the inherent story-telling found in Arabic epics with the strength of the political manpower of contemporary music. In his song, "Destiny", he states "It's hard living in the West when you know the East has got the best of me."32 Having lived in both spaces, the Middle East and the U.S., he sees both areas as two parts of one big geopolitical narrative, where each part gives life to the other. Drawing inspiration from the American black culture, Offendum also builds parallels between the black experience in the U.S. and the current conditions for Muslims, stigmatized throughout the world. Offendum bridges this cultural gap by focusing in particular on the universal struggles of peace and justice that bind humanity together. He is hopeful that his verses speak not only to Arab Americans but to all people, especially those who are suffering. He wants his music to reach the ears of immigrants, students abroad, and refugees: the ones with "hybrid or hyphenated identities." 33

Offendum declares his hopes for justice and peace and prides himself on being an educator using ideas as opposed to a seller of records. Since first hitting the world stage in 2010, he has made contributions to social justice, political transformation, and intercultural dialogue. ${ }^{34}$ For example, his debut album Syrianamerican A combined Arabic identity with an American outlook. Likewise, his track \#SYRIA, which calls for the downfall of Assad's regime and promises a brighter future for the war-torn country, was so powerful and belligerent that he was officially banned from visiting Syria. ${ }^{35}$ Offendum has been featured around the world, at festivals in Europe; local youth groups' meetings in Southern California; university lectures in Sydney, Australia and Minnesota, U.S.; concerts in Malaysia; and music videos recorded at the prestigious Berklee College of Music in Boston. Throughout his short career, he has also dedicated a large part of his time to humanitarian relief agencies, raising hundreds of thousands of dollars for Palestine, Pakistan, Iraq, Haiti, and most recently Syria. ${ }^{35}$ Offendum has been featured by many well-known news outlets including The LA Times, Aljazeera, Vice, The NY Times, and Rolling Stone. Most notably, he credits his success to the internet and social media platforms that help get his message out. As of August 2016, Offendum has approximately 30,000 likes on Facebook, 12,200 followers on Twitter, and 11,500 followers on Instagram; these media help him reach out to the entire world.

"Destiny"

"Destiny" is perhaps Offendum's most notable song because it lays the grounds for better understanding the complexity of the current conflict in Syria by presenting Syria's modern history. The song begins with perhaps the most important part: the chorus. Like in poetry, the first line of the chorus becomes a repetend throughout the song, drags the audience into the song, and captures attention: "You are my destiny." Offendum uses the collective second person pronoun "you" to refer first to the American listeners who constitute the first intended audience of the song, and second to the Syrian people and their current suffering, both of whom represent his "destiny" as a poet, performer, and educator. They are the reason why his music constitutes an activist platform that aims to raise social consciousness and foster social justice both in the U.S. and the Arab world. The remaining chorus captures the context that renders Offendum's destiny problematic:

It's hard living in the West when I know that the East got the best of me...

could be looking in my eyes - but you'll never really see the rest of me

can you hear me, maseer? Bilingual's what I'm blessed to be

7 amamet Salameh - ifta7ee ajni7 atikee oo Geeree

Dove of Peace spread your wings and fly over me.

His ethnically complex identity creates a rift in his global being, where the East and the West are the two ends of a fluid continuum that get polarized and repolarized by conflict. Offendum The speaker feels the pull of the East in the West a lot more vividly, particularly because his family and his compatriots in the East are suffering while he is privileged to live in the West and away from war. The guilt of not being able to share in their agony morphs into a feeling of indetermination in the West, where his identity is being misread, as the line reads, "you'll never see the rest of me." This means that the observer will never be able to comprehend the entirety of his identity, primarily defined displayed through bilingualism. Indeed, the last line of the chorus is sung in Arabic. This message is quite important because it begins to outline Offendum's background as an individual capable of problematizing identity and evidencing its complexity. This ability allows him to communicate with multiple people across the 
world as he sends out his peace message. The last line of the chorus translates to "Dove of Peace, spread your wings and fly over me," suggesting that Offendum ultimately wants the war to end so that people in his Eastern home country can be safe.

Transitioning from the last line of the chorus, the first verse of the song is performed entirely in Arabic. Here is an English translation:

Consciousness? What consciousness - where is it?

Take a walk with me

Here - in this valley between two "mountains"

where the source of love for both "sides" can be found

our mothers like us - but dont like our foul language

so lets keep this between the siblings

the best of Arabs \& Americans

and may God have mercy on all our dead

Songs i sing like the Mahatma ("aghani-d" means these songs ... which sounds like Ghandi \& in turn relates to the next quote)

If we say 'an eye for an eye'

there wont be any eyes left in Sham

Bilad al-Sham (i.e. greater Syria ... since "Sham" refers to Damascus ... but "bilad al-sham" means Greater Syria ... the

distinction is made for the sake of unity across borders)

from Palestine to the mountains of Lebanon

before they made up these borders

from Iskandaroon to Kurdistan - understand?

Genghis Khan never deceived us quite like our "paternal cousins" (Khan also means deceive in arabic)

but our blood is their blood

children of Adam

who built their sins

upon our shoulders

we carried their burden

why?

God knows

but listen, this little firecracker \& bicycle are better for you than 100 million guns - wanna know why?

because they don't like seeing you smile

but smile you will - in your human being

a young cultured/educated Arab male - give them your stamp of approval

and if they still don't accept you then remind them of the words of Elliye (Elliye Abi-Madhee is a famous Lebanese poet who wrote a poem that started with the following words)

"How soon a piece of dirt can forget that that is all he/she really is ... just dirt" (i.e. we are all from this earth \& will come back to it ... so there is no logic in viewing yourself as better than someone else)

and that my friend

is ... our Destiny

In this stanza, Offendum offers a topography of Syria that maps onto its diverse cultural geography. The reference to "the valley between two mountains" succinctly depicts the way the land is laid out in Syria, with the Jabal al-Druze Range bordering it in the south-west and the Taurus Mountain in the north-east dissected by the Great Rift Valley and the Valley of the Euphrates River. ${ }^{36}$ This geographical binary constitutes the "source of love" for the two "sides," a reference that could be interpreted literally as the East and the West, or metaphorically, as in opposites that create conflict in Syria. If the latter is indeed the case, one may notice that Offendum condenses an otherwise extremely complicated war that engages several groups into a rudimentary but forceful opposition of two sides. Considering the references to these two sides in all of Offendum's music, one can understand them as denoting the collective "people" versus a disappointing government. With the following line: "our mothers like us, but don't like our foul language," Offendum further characterizes the conflict as undignified; however, the ability to "keep this between the siblings," or to understand that all families wrestle with conflicts but eventually manage them, constitutes a characteristic of both Arabs and Americans. Offendum believes that no society is devoid of conflict, but as long as solutions can be found, both Arabs and Americans have a chance at restoring peace in their respective regions. While it is not clear from the song what specific conflict Offendum references in regards to the U.S., one can simply follow the daily news to understand that this democracy is not perfect by any means. 
Further, Offendum offers a solution to conflict by referencing a famous quote articulated first by Mesopotamian king Hammurabi and then again by Mahatma Ghandi. The line reads, "An eye for an eye leaves the whole world blind." The idea of "an eye for an eye" alludes to the ideology of non-violence, widely embraced by many leaders throughout the world whose strategies in appeasing the conflicts in their respective nations included peaceful resistance. For Hammurabi, the quote represented a section of a code of laws that he designed to withstand tribal feuds and maintain the cohesion of his empire. ${ }^{37}$ With this same idea of "an eye for an eye," Gandhi condemns state violence against its citizens and warns that revenge only breeds more conflict. Marshaling the Gandhian excoriation, Offendum sings, "if we say 'an eye for an eye'/ there won't be any eyes left in Sham", condemning state violence against the protestors.

The idea of unity across borders continues in the next lines of the verse, in which Offendum draws the map of a Pan-Syrian land that existed as such until the dissolution of the Ottoman Empire and the formation of the state of Israel. This old country, Offendum tells us, stretches "from Palestine to the mountains of Lebanon/ before they made up these borders / from Iskandaroon (Alexandria) to Kurdistan - understand?” He may be drawing this inclusive map in order to hint at the disputed ideology of Pan-Arabism. Secular Arab nationalist Abu Khaldun Sati al-Husri, for instance, declared in 1964 that "people who spoke a unitary language, have one heart and a common soul. ${ }^{38}$ As such, they constitute one nation, and so they have to have a unified state," in response to his conviction that Arab states were created by European imperialist powers. Political scientist Adeed Dawisha contends that the founders of the Ba'th Party felt the same way as al-Husri almost twenty years before. ${ }^{38}$ Offendum is suggesting here that the borders drawn by the Western powers helped only to create distance and conflict between the people, dividing them both geographically and emotionally into "opposite" camps. Offendum encourages all to unite in fighting against oppressive rulers.

The song continues by romanticizing the past and setting it in stark contrast to the disheartening present. Comparing former rulers and present men of power to Genghis Khan, Offendum invokes the Il-khanid Dynasty during which Iran and neighboring areas witnessed a renascence period under the rule of Mahmud Ghazan. ${ }^{39}$ Unlike him, Syrians' "paternal cousins" — a reference to Christian Westerners, descendants from Isaac and "cousins" through Abraham with Ishmael and the Muslim Arabs of the Middle Eas ${ }^{40}$ — have disappointed the Syrians with their inability to offer feasible help. However, "Khan" in Arabic also means "to deceive," a translation which transforms this line into a sarcastic commentary on Syrians' general lack of support throughout the ages.

Offendum's insistence on peace and understanding is underscored in the next lines of the verse that discuss humanity's common descent. Offendum points out that although people live in different areas of the world, they all share the same blood as children of Adam. The reference to Adam, however, only helps tie three main religions, excluding still some from this common ancestry, perhaps quite willingly. University of Southern California historian Sarah Gualtieri indicates that the alignment between Syrian immigrants in the West and European Christians is not accidental. Gualtieri argues that the defining of Syrianness within the U.S. racial order helped strengthen Syrians' application for U.S. citizenship and their inclusion in the body politic during the first decades of the $20^{\text {th }}$ century. ${ }^{41}$ The implicit association of the three Abrahamic religions and whiteness as a civic status in the U.S. may then help Offendum establish Syrians' legitimacy in the U.S. Nonetheless, if one takes the Biblical parable of the first humans symbolically as a story of origins, then perhaps similar stories of initial couples giving birth to the rest of humanity constitute a mythical paradigm shared by many more communities than the Abrahamic three. Although Offendum invokes the Biblical story of Adam and Eve as a common belief shared by Jews, Christians, and Muslims, he is also acutely aware of the conflicts throughout the ages between the three communities who have employed religious rhetoric as a means of mobilization. However, precisely because these three communities share the same bloodline, the same original saga, Offendum suggests that they should be able to come together in peace.

The remainder of the verse, then, continues to emphasize the need to reinforce equality among these three cousin communities so that Arab Muslim individuals, whose public image has been thoroughly suffering in the U.S. post 9/11, can regain credence and agency. Offendum says “because they don't like seeing you smile/but smile you will - in your human being/a young cultured Arab male - give them your stamp of approval" to show not only that Syrians, but also Middle Eastern Arabs must be accepted by their respective governments, societies, and the world at large. A poet himself, Offendum references the Syrian-LebaneseAmerican poet Elliye Abi-Madhee (known in the West as Elia Abu-Madi), whose poetry insists on the futility of conflict and the value of communication and understanding. Like many other Arab New Yorker poets deeply affected by the conflicts in the Middle East, Abu-Madi and his colleague Khalil Gibran invested their efforts in forming immigrant cultural circles rather than political powerhouses. ${ }^{42}$ In a poem translated into English on a blog page entitled "The Moor Next Door," Abu-Madi says, "Smile, it is enough that you are even alive, and have no want for friends and well-wishers," thus encouraging the reader to appreciate life. ${ }^{43}$ In Offendum's song, Abu-Madhi wonders rhetorically, "How soon a piece of dirt can forget that that is all he really is - just dirt?" No matter who a person is, one cannot view themselves as better than anyone else because, in the end, we are 
all transitory on earth. The reference to the human body as a piece of dirt may again be connected to the Biblical original parable describing the creation of man from dirt. The fact that all people are ephemeral despite their social and political positions underscores the urgency of Offendum's plea that Arab men's dignity be recognized and respected. In the last line of the stanza, "and that my friend is our Destiny," Offendum capitalizes the word Destiny perhaps to indicate that Destiny itself is one for all of us: we will all eventually perish.

The second verse of the song, written and performed in English, underlines that despite differences, Easterners and Westerners cannot live without one another. Although he does not use the actual Orientalist terminology that splits the world into the East and its supposedly better half, the West, Offendum employs the binary on which Orientalism is constructed. In Edward Said's terms, the East or the Orient was Orientalized and made distinct from the West not only because it was discovered to be Oriental, but also because it was made Oriental. In other words, the East in this Orientalist paradigm exists as a discourse and a system of knowledge that was produced by Western imperialist institutions and exists in an uneven exchange of power with the West. ${ }^{44}$ Defensive, Offendum references this binary in order to subvert the power relations it has cemented and to do away with it. Only by demonstrating that this uneven power structure between the two areas and peoples is unfounded, can Offendum dissolve it. Allusions to the Arabic linguistic and cultural influence in the West are scattered throughout, indicating again the his bilingual consciousness. The verse begins by illustrating the contrast between an English and an Arabic speaker whose main difference rests in the fact that they each write in opposite directions. This distinction - a frivolous and arbitrary one-is symbolic of the struggle to "fit in" that a foreigner faces in a new environment as they reject assimilation.

I write right to left. You write left to right.

Metaphor of a foreigner's plight. Dressed to type.

Stereo and a mic. Scenario of a fight.

The burial of a white Imperial at his height.

A Turkish Rapper's Delight, Semitic etiquette might

just have you rollin' your "R's." Poetic and light.

And grab a hold of your sorrows to relieve your tomorrows.

Make it easier to borrow the aesthetics you bite.

Like all the Arabic loanwords from Spaniards and Moros.

The Karma of Inquisition. Visions of horror.

So who's the explorer? Really was it Columbus?

Muhammad al-Idrisi or Alfaragnus?

Throw a Hobson Jobson while you figure it out.

I'm gonna start with a cipher that's a siffir [zero] - no doubt.

See you might not have learned to live with me,

but sure as hell can't without. I'm your destiny.

The two different systems of writing represent symptoms of the Orientalist tendency to interpret difference as threatening the authenticity of the self because the "other" corrupts the self. This difference creates intolerance for those who are racially, ethnically, culturally distinct from "us." Dressed differently and rapping against intolerance, Offendum himself inhabits the "scenario of a fight" because of his capacity to instigate an unfavorable reaction from listeners. His identity as a Semite "rolling his r's" and as the performer to bridge the East and the West sets him in opposition to a "white Imperial," a phrase that carries historical and political significance as it echoes Rudyard Kipling's conception of the White Man and his "burden." 45 Offendum hints at the reality that white imperial forces such as the British, the French, and the American, have manipulated political outcomes in the Middle East for centuries. ${ }^{46,} 47$ The phrase "Turkish Rapper's Delight" references the title of the Sugar Hill Gang's 1979 song "Rapper's Delight," the song credited with creating a market for studio-recorded hip-hop in America. With this reference, Offendum communicates that like Sugar Hill Gang in the U.S., he plays an equally important role of introducing hiphop to the Middle East and locates this birth moment in a geopolitical site-Turkey—that constitutes a literal land bridge between the East and the West. The reference to the sweet-Turkish delight—-may also indicate that Offendum is already aware of the difficult position he inhabits: the danger that his music may be taken as a sample of Orientalist exoticism in the U.S. In order to bridge the gap that this difference has created between Middle Eastern and Western individuals, Offendum points out the ways in which Western languages and Arabic share parts of their lexicon. Loanwords are words adopted from another language but preserved almost intact in the borrowing language. For example, the Moors facilitated a linguistic exchange between Arabic and Spanish. Arabic neologisms in Spanish were highly criticized by the Spanish Inquisition whose goal was to purify the community of all elements perceived as threatening Christianity, including foreign elements of language. However, Offendum attempts to rectify history by underscoring that Arabic has actually yielded fantastic contributions to civilization before European cultures added their mark to social progress. 
Offendum questions the Eurocentric perspective in world history where individuals such as the Portuguese Columbus are recognized for their discoveries, when world explorers from the Islamic world predate Columbus and remain unknown. For instance, Offendum forces his audiences to consider Muhammad al-Idrisi, an Arab geographer in the early twelfth century who wrote a book titled "Kitāb nuzhat al-mushtāq fī ikhtirāq al-āfāq" or "The Pleasure Excursion of One Who Is Eager to Traverse the Regions of the World”, also known as “The Book of Roger”. Roger II, a Christian king in Sicily, hired al-Idrisi to create a map of the world, the first known map that combined descriptive and astronomical geography long before Columbus set on his transatlantic excursion. ${ }^{48}$ Another historian mentioned in the verse is Alfaragnus (Abù l-'Abbàs A mad al-Farghàni), one of many Muslim astronomers who lived and worked during the Islamic Golden Age, a historical period marked by scientific progress and that began in the $9^{\text {th }}$ century, hundreds of years prior to the Western Renaissance, the European era of progress and exploratory discoveries. ${ }^{49,50}$ Offendum uses these examples of Muslim intellectuals precisely because Orientalist epistemologies continue to marginalize or exclude them altogether. He wants the audiences to understand that greatness has come out of a people that not many consider important to the beginning of the worldwide modern age.

Another such moment of cultural misrecognition is alluded to with the phrase the Hobson-Jobson. The Hobson-Jobson is a glossary of Anglo-Indian words that was written in 1872 by Colonel Henry Yule and A. C. Burnell, to evidence the common vocabulary between English and Hindi. ${ }^{11}$ However, the phrase Hobson-Jobson is also a derogatory locution created by British military men who happened to witness the Shia festival of the Muharram, a period during which Shia Muslims mourn the death of Imam Hussein, and misheard the phrase commonly chanted during this festival: Ya Hassan, Ya Hussain. ${ }^{52}$ Therefore, to throw a Hobson-Jobson at the West would mean to misinterpret and mock a western phenomenon of great religious importance. Offendum recognizes that the cultural misinterpretations and derogatory renditions are offensive and dangerous. In contrast, awareness_ or deciphering the cipher (Siffir in Arabic means both cipher and zero; the English word "cipher" is an Arabic etymon)—can help people respect each other.

The final verse of "Destiny" warns that blaming the current conflict in the Middle East on a slavery-like colonial system will not help end it.

See [Arabs] shooting at each other from Iraq to [Palastine].

Syria to Libnan [Lebanon], Algeria to Sudan.

Pedagogy of the oppressed, tricklin' down.

Conquerin' through divisions and sadly this isn't the first time.

One land, one love, one chance, one blood.

No fuss, no fight? Yeah right, young blood.

AK's cheaper than a book, crooked leaders in a hook

Gettin' fished out, missiles gettin' dished out,

Bitched out by the West. Press gets a big shout.

From the people getting' rich out of this (bout).

Now what's this really all about? Land, money, or power?

It was the colonizer's fault, but now it's really just ours.

Leavin' a sour taste in our mouths like generational slave names.

Whenever speakin' out, out-spoken leaders gettin' taken out.

Quicker than belligerent drunks in a bar.

We a far cry from livin' as one.

The verse establishes that although conflict in the Middle East may have been sparked by colonial conquest, today the cause of the conflict has morphed into something homebred. "Shootin at each other" in Iraq, Palestine, Syria, Lebanon, Algeria, and Sudan represents a phenomenon that stems out of a learned way to oppress and live under oppression. The reference to Paolo Freire's Pedagogy of the Oppressed ${ }^{53}$ helps explain Offendum's understanding that in the Middle East, the state of being exploited is learned and replicated from generation to generation by “conquerin' through divisions, [which] sadly ... isn't the first time.” Oppressive governments have overpowered the people in Egypt, Algeria, Tunisia, Yemen, Lebanon, and Syria by dividing them and turning them against each other. The fact that "AKs [are] cheaper than book[s]" highlights the sad reality that people are more enthralled with war than with education, because, Offendum explains, “crooked leaders in a hook/[are] gettin' fished out/[while] missiles gettin' dished out." This situation in which the persons who are truly at fault never receive their punishment seems to benefit rich sponsors who continue to entertain the conflict and maintain the crisis. We may recognize in Offendum's "calling out" the U.S. position complexly described by Emile Hokayem, Senior Fellow for Regional Security at the Middle East office of the International Institute for Strategic Studies. In his book, Syria's Uprising and the Fracturing of the Levant, Hokayem argues that a series of circumstances, such as the U.S. venture in Iraq or the general post-Bush U.S. tendency to remove themselves from domestic matters in other countries, prevented the U.S. from an active engagement in Syria after $2010 .{ }^{54}$ The media alone, contends 
Offendum, seems to receive financial gains as they create information about the conflict, while no one in the U.S. takes the problem seriously. He wonders who really profits from the conflict in general, and why the conflict continues to take place, but he has no answers. The final message of the verse, ending with the line "we're a far cry from livin' as one", is that although some strides have been made in the Middle East and in Syria specifically, human beings still refuse to live as "One land - one love."

\section{"Syrianamerican A"}

Much like "Destiny," "SyrianamericanA" also denounces the destruction of Syria, albeit from a historical angle of colonial conquest. Before the music starts, the video begins with a newscast dialogue between two male voices who discuss the origins of the name Syriana. The dialogue mimics an interview between a host and an informed speaker, well-versed in the political history of the Middle East. From this dialogue, the audience learns that the European powers were able to redraw the borders of the region known as the Levant after WWI. The voice of the scholar states that "Iraq was a fake country" because it merged together three provinces of the Ottoman Empire in order for the European powers to be able to better control the oil assets in the region. Syriana is, therefore, a coined name that designates an oil-rich territory financially attractive to the European powers. The historian ends by highlighting that Syriana is also a "metaphor for the Middle East" which was "made out of false borders." As the speaker finishes his sentence, the music begins, and we are introduced to Offendum's voice singing what we recognize as the chorus "SyrianamericanA is where I wanna be,/ There I'm honored/ 3iish Nirvana, Peace and Harmony."

To contextualize the video's opening dialogue, the modern history of Syria must be further elaborated upon. In the nineteenth century, Greater Syria denoted a territory comprised of three Ottoman provinces stretching across the modern-day states of Syria, Lebanon, Jordan, and The Palestinian Authority. ${ }^{55}$ Historian Ayse Tekdal Fildis offers a brief history of Syrian management during the first half of the twentieth century. The Skyes-Picot Agreement established between the Allies in 1916 split the territory of the Middle East as follows: Iraq and the Gulf region including Palestine was occupied by Britain, and Syria and the Levant was occupied by France. France's concern in the region included monitoring the development of Arab nationalism in order to prevent its infiltration in North African French colonies. When Amir Faysal Ibn Husayni managed to form an independent Arab government in Damascus, France had to decide whether that would be commensurate with their interests. In 1920, Faysal declared war on France, which ended in a loss for his army. After winning the war, France decided upon a mandate in Syria according to which they would recognize Faysal's partial political independence as long as Syria remained under French military occupation and accepted the mandate. ${ }^{56}$

Offendum recreates the term Syriana as SyrianamericanA. On the one hand, he reimagines this European-dominated space by reprogramming its colonizer's history and locating it in America. SyrianamericanA would then become a constructed space by an American imperial force similar to the European powers alluded to in the song's introduction. To illustrate this point, Offendum chooses to end the term in capital letter: A. Since capital letters usually mark the beginning of proper nouns in English, this notation indicates that we can read the term both from right to left and from left to right, in the style of the Arabic language. Reading the name SyrianamericanA from left to right gives us the logical symmetry of Americanasyriana. Uttered this way, the term emphasizes America, the general appellative for the U.S., as the dominant power in Greater Syria.

Another way to read SyrianamericanA is by splitting the compound noun into its two parts: "Syrian" then denotes ethnic or national belonging while "Americana" becomes a term which reimagines America as an imperial consequence, just like Syriana. By indicating that Syrian(s) dominate the American imaginary, Offendum empowers a small category of Arab-Americans who have become the target of Islamophobic and terrorist accusations over the past few years and among whom he himself identifies. In this space of the SyrianAmericanA, the speaker feels "honored to be," indicating his perceived privilege of belonging to that space and of reimagining the American dream. For Offendum's speaker, the American dream is "peace and harmony." As a destination point for many refugees seeking justice and equality, America is indeed at least imagined as a place of peace and harmony. However, one may interpret Offendum's American dream sarcastically as well: America boils with Islamophobia, racism, and xenophobia, especially this election year, to such an extent that neither harmony nor peace are actually attainable.

In the chorus, Offendum introduces an Arabic term—3iish_-which translates to "life" or "living." This choice foreshadows then the very first stanza sung entirely in Arabic. A translation of this stanza follows:

I work on my issues,

My attendance is essential.

Forced and proud of my roots,

Why be sorry?

They destroyed my constitution

And erased my Arabic eras.

Hey, days and months come and go, go round and round, 
Who could understand the wall, whatever its height, and the cost, whatever its value?

He didn't sell his share,

Nor his tradition and story:

Aleppo pistachio,

Arabic literature,

My misery.

Robbery, prohibition

Used to answer the messenger of the earth's creator

In the past, present, and by order.

Flamed, flaming, flame up the coal,

My thoughts are running like a river

And the source is my brain,

Cold and zamzam

Bomb-shoot!

Shoot your head

You are in Afndam's house,

Misery, family,

A family of mud and blood.

What are your origins?

If you stay this way, you'll regret.

This way, you'll regret and cry.

Here, the speaker bemoans the destruction of a Middle Eastern culture intentionally left ambiguous. The oppressor, crystalized in the collective pronoun "they" as a way of amassing various power groups with interest in the Middle East, has destroyed the speaker's culture, history, and people. Subtle references to the modern history of Palestine and its slow conquest are made throughout the verse, but one line stands out: "Who could understand the wall, whatever the height, and its cost..." Built over sixteen years ago, the wall that delineates the West Bank from Israel cost over $\$ 2.6$ billion to be erected and an annual average of $\$ 260$ million simply to be maintained. ${ }^{57}$ Journalist Mairav Zonszein details that "most of the barrier comprises a set of 2-meterhigh, electrified barbed-wire fences with vehicle-barrier trenches and a 60-meter-wide exclusion zone on the Palestinian side. But in more densely populated urban areas, particularly those around Jerusalem, ... space limitations prompted the Israelis to instead build (sic) a concrete wall to the height of 8 meters." 57 The remainder of the verse then zoom in and out of specific Middle Eastern areas: If the reference to "Allepo pistachio" hints specifically at Syria, "Arabic literature" again broadens to encompass the Levant and the Arabic peninsula.

Not only this destruction, but also Quranic history become the speaker's personal story, in which the first person pronouns, (I, me, my) morph into the third person (he, Afndam) and back. This way of creative thinking is described in the lines:

My thoughts are running like a river

And the source is my brain

Cold and Zamzam

Bomb-shoot!

The image of the river as symbolizing the rush of thoughts the speaker wants to express in his verse is not surprising, but perhaps the reference to the Zamzam needs explaining. The Zamzam is the name of the Biblical river that sprang up in the desert as a result of Hagar's invocation that God helps her save her sick son, Ishmael. Frightened by the sudden onset of so much water, Hagar cries, "Zamzam" or "stop, stop." Offendum compares his performative power to that of this spring, but more importantly, to its reputation as being unstoppable, arising from unlikely places, leaving a permanent mark that transcends history and providing nourishment and sustenance amidst a bleak, unforgiving background. For many Muslim believers, visiting and drinking from this river remains a pilgrimage recommendation. For Offendum, invoking the Zamzam River symbolizes his resorting to a tradition that he reclaims and that informs his thinking and creativity.

The second stanza turns more explicit in terms of the destruction that war produced in the Middle East. As the speaker works his way into building this complicated image of a devastated place, he defines home as a "poem" that sounds "homesick." The idea of having one's home in a poem, though romantic, underscores this home's lack of specific physical borders. This is a nomad's dilemma: carrying the idea of home with oneself in one's poetry constitutes a way of life among Bedouin and other desert tribes. The spelling of the word homesick with the syllable "home" in parentheses further highlights the ambiguity of the word. Is a (home)sick person sick of their home, a scenario which may easily fit with the disillusionment of Syrian citizenry at the ability of 
their "home" to offer security and safety? Is a (home)sick person someone who feels sick at home? Someone who misses their home to the point of sickness? Offendum's already acute awareness that language is arbitrary and untranslatable allows all these questions to arise.

With the next line, the extended metaphor implicitly compares "home" to a "phone click-clack tone" and pushes the notion of belonging further into the abstract and the absurd. The nonsensical nature of "home" affords death and destruction to find their place in it. The imperative "lift that bone_-give it back to him" illustrates the ruining of "home," because to be able to reclaim "home" as a space of belonging, one needs to recognize their responsibility in creating ruin and returning victims' bones to their own community. Furthermore, to be able to return one's bones symbolizes the need to become accountable for murder, even when one did not directly commit it, to count one's sins like "knots on a rope," or the tasbih, the prayer beads that many Muslims use to glorify God and cleanse the soul through the rhythmic chanting of phrases.

Other references in this stanza build specificity to this space that is being destroyed. Iraq is being identified by name as an epicenter of damage, as "bombs in the sky/ make Iraq bloom." The paradox of imagining bombs as the cause for something to bloom heightens the irony because blooms celebrate renewal, while bombs kill. The speaker expresses his bewilderment at the reason Iraq had to be wrecked, which is the fact that this state, "a modern Babylon, was responsible for the problems in the Fertile Crescent." On the one hand, the symbol of the crescent, which is also fertile, reminds of the grandiosity of the Ottoman Empire. On the other hand, the hilal (crescent moon) populated many pre-Islamic poetic texts as a symbol of friendship and guidance offered to the lonely traveler through the desert. ${ }^{58}$

The casualties of war are always innocent people because, the speaker says, when they murder peasants

and they find men will never learn their lesson, it's a fine line 'tween a smith $\mathrm{n}$ wessun hindsight $20 / 20$.

Responsible only for their agricultural chores, peasants carry no guilt. Yet, they represent the majority of Iraq's agrarian population who, according to Offendum, lost their lives. Indeed, the Waston Institute for International and Public Affairs at Brown University indicates that approximately 165,000 Iraqi civilians have been killed since the U.S. invasion in Iraq, although the actual number might be a lot higher. ${ }^{59}$ Those responsible for their murder (referred to again through the collective and ambiguous third person plural pronoun), however, never learn from their mistakes, and the cycle of senseless killings continues. The phrase "hindsight 20/20," meaning "one understands an event correctly only after it takes place", is usually used with sarcasm as a means to criticize a poor decision. However, we must be aware that the critic in the present has access to information that would not have been available to the person acting on their decision in the past. And yet, the "blessin" of hip-hop music is that it is able to lift the veil of ignorance and reveal the truth.

\section{"\#SYRIA"}

"\#SYRIA" is perhaps Offendum's most popular song on YouTube, with 265,228 views. The music video for the song was produced by Sami Matar, a Palestinian "American music composer and music producer for film, television, video games, and popular music." 60 The song's video presents footage from one of the revolts that took place in Hama on the $22^{\text {nd }}$ of July, 2011. Incorporated into the song's melodic line and chorus, is the slogan chanted on the streets of Hama and throughout the Middle East during the Arab Spring: "alsha3b yureed isqaa6 al-nitham" or "the people want to overthrow the regime." Speaking to the power of this phrase, one of the YouTube audience members listening to this song indicated in the comment section that "We used to [listen to] this song secretly, fearing that if we got caught, we would have been taken and tortured to death by the Assad's intelligence (Mukhabarat)." ${ }^{1}$ Connecting the discourse of the revolution to that of hip-hop, Offendum creates a close connection between art and reality, emphasizing the former's ability to mirror the latter.

The song's first line exposes the overarching aim of Offendum's hip-hop artifacts: "the purpose of these verses is to unify the masses." The notion that revolution can only be achieved through unity drives the song forward as the speaker explains:

from city streets to countryside

Mountain tops to coastal tides

Muslim, Christian, women, men and children

let's keep hope alive

stand in solidarity with all your fellow citizens

peacefully protesting for the end to all the militancy 
This song is the most politically direct in opposing the Assad's rule and unmasking its crimes. However, Offendum does not want his audience to understand this song as a simple government-bashing attempt. Rather, he insists that we receive the song as a plea to the world that we must become aware of the extent of Syrian citizens' daily suffering at the hand of their government. On his blog at offendum.blogspot.com, the rapper states that "I am a human being who believes in dignity, freedom \& equality for allno exceptions ... I am an artist who strives to reflect those ideals in lyrical form ... This is but a small contribution when compared to the sacrifices being made by beautiful, peace-loving Syrian people on a daily basis." ${ }^{\prime 2}$ This assertions renders explicit the purpose behind his music: to inform in hopes of social justice.

The video ends with more footage from the protest in Hama, where the protest leader, poet Ibrahim Qashoush, recites one of his politically-charged poems and instigates the crowd to a call-and-response game where they chant "Bashar, depart from here." As a result of his non-violent resistance and offensive poetry, Qashoush was found dead in the Assi River weeks after the protest, with his vocal chords ripped out, a warning from the Syrian government to those who might use their voices to criticize the regime that they will be similarly punished.63 Both Offendum's and Qashoush's words reflect the teaching of Archbishop Desmond Tutu — a South African social rights activist whose work against apartheid became notable world-wide in the 1980s and whose quote Offendum chooses to list on his website above the video for \#SYRIA. Archbishop Tutu said that "if you are neutral in situations of injustice, you have chosen the side of the oppressor."'64 Archbishop Tutu's wisdom echoes Martin Luther King Jr.'s famous 1967 remark that "In the end, we will remember not the words of our enemies, but the silence of our friends." Music, and in particular Offendum's songs, ensure that what the Syrians remember is their allies' loud voices of support. Qashoush lost his life by choosing not to remain neutral. We can only hope that Offendum's U.S. residence can offer him the protection Qashoush did not have. One thing is clear: poetry, or in Offendum's case, hip-hop, can and will carry its political message loud and clear hoping that we, the audiences, can demand social justice for both Syrian citizens and Syrian refugees.

\section{CONCLUSIONS}

Hip-hop across Middle Eastern society is a diverse and global medium, seen as an art that not only celebrates street culture and resistance, but also appeals to the stigmatized and the oppressed. At the heart of hip-hop is the artist who can use the potential of hip-hop to inspire and instigate change. Offendum is one of these small-time artists who uses hip-hop to make a change in a big way. He has gained critical acclaim for his songs about the popular democratic uprisings throughout the Middle East and North Africa during the Arab Spring. ${ }^{65}$ In fact, his song “\#Jan25”, which went viral in 2011 and became the anthem of revolution in Egypt, is often cited as being the song that spread international hip-hop within the Middle East, although in actuality, Middle Eastern hip-hop stretches further back. ${ }^{66}$ This misunderstanding is largely due to his personal style that he describes as "conscious rap" or "political hip-hop." His music is brave, defiant, and brash, but also underlying it is a yearning and deep-seated pain. He openly admits that the Arab region has taken a sharp turn for the worse but he still remains hopeful in the people. "Equality and human rights for all people: both in the Arab world and at home" is the ideal he preaches. "Apathy is not an option," when beneath everything the root is "real human suffering." 67 Offendum feels the obligation and responsibility to fight for the rights of the oppressed in the pursuit of his vision, in which all people can unite in the spirit of resistance in solidarity with one another.

It is hard to assess the actual outcome of Offendum's songs in establishing awareness, dialogue, and social justice for Syria. Nonetheless, a look at the comments that his Middle-Eastern and non-Middle Eastern viewers have posted on the YouTube pages for his songs reflect a general sense of gratitude and agreement with the his ideal. For example, r.jrjun says "music breaks the boundaries of [race] and religion." Zahra Almosawi posts "he should really be more out there, he's amazing." Fatima Mousa writes "pure talent." S. Kelly notes "Entire album is fantastic. I'm Irish American. Viva Palestina! Long live Syria. And today, Ramadan Mubarak to all my Muslim friends. May the year be full of blessings for you." Yusuf says "amazing” and Burak Ayan posts "Salam from Turkey, to all my brothers and sisters... thanks to Omar Offendum for this excellent rap song." Mohammad xm ponders, "It's true when he said 'AK's cheaper than a book." Bandar Orabi adds "Respect from Kingdom of Saudi Arabia," and Ali Rafsanzani comments in Arabic "Ya hayati," which translates to "You, my life," probably referring to how the song reflects so closely his own experiences. Yasmeen Masalme writes in Arabic “Oh, Syria, Lord oh.” Mobarak Alkhozaei adds, "Love \& respect from Mecca" and Aimen Ben Ltayfa "Much love from Tunisia." Other comments locate the speakers in Palestine, Qatar, and Iraq. By and large, Offendum's fans consider his music timely and effective.

Paying closer attention to the comments posted as reactions to the song \#SYRIA, one discovers that Offedum's lyrics foster not only gratitude, but often complicated political debates about the outcome of war in Syria, the West's involvement in mitigating conflict, or Bashar Al-Assad's culpability. Many Middle Eastern respondents ${ }^{\mathrm{f}}$ agree with Offendum's political stance: Iblis Shahsia, for example, posted in July 2016 that "Bashar is a bad man he is killing Syrian people." Similarly, in April 2016, Marwaan Ahmed posted "Omar, Thanks for your powerful words...Assad will go sooner or later. May God have mercy on al-Qashush's soul!" A year ago, Cherkess warned that "Victory for our glorious revolution... god bless Syrian freedom fighters." Sometimes, the comments reflect strong political views regarding international relations. For instance, Salah Bakr posted in 2015, "Free Syria. Assad cannot make peace in his neighborhood and all what he can do is destroying cities. Why?? Because he is just a good boy for 
Russian and Iranian politics agenda (putin \& hassan rawhani) because they think that if Syria got free it will be no longer available for their dirty business." However, these are not the only voices one can hear as reaction to Offendum's song. Some Middle Eastern commentators support Bashar Al-Assad's regime. For instance, two years ago, Hadi Assaf posted the following comment: "The rebels are only terrorists. They are not fighting for democracy, but only for the difference in ethnicity. So, I'm pro... Assad." Another individual whose You'Tube name is area40five replied: "That's what the Iraqis said when the Saddam Regime killed and tortured Shia, the Baath government call Shia rebels fighting for their rights and impunity terrorist, and Israel labels Palestinians resistance squad terrorists too. FSA are the equal fighting force as once the Shia's in Iraq and the ... Palestinians, you shouldn't degrade them because a Sunni force it's on a mission to topple a Shia dictator, you should support any one against a dictator regardless of their beliefs" (sic). Michael Hajd's post also expresses disagreement with Offendum's views despite the fact that he agrees with the ultimate goal of freeing Syria:

Protesting peacefully? You mean taking up arms against a government that is facing pressure from Israel, the U.S.A., and the U.K. What would you like Bashar to do? Whether you support Assad or not, you cannot criticize him for bombing cities with terrorist cells. Let us defeat ISIS, Al Nursa, and actual threats to Syria. The rebels have a fair cause, but siding with terrorists is no means of political process. Making a song that defames a leader who is loved by Alawis, Christians, and Arabs alike also doesn't help anything. You should sing of Syrian unity; free of political allegiance. Defeat ISIS, Al Nursa, and Da'esh before you kill other Syrians. Long live Syria!

Other commentators, especially non-Middle Eastern, become emotionally engaged and perhaps a bit more vocally so. For example, Adrien Hartemann posts a reply to Felicia Adele in July 2016 explaining at length his view on the causes and development of the war. DaN3xeEconomist posts "[the fall of the regime] hasn't happened in 5 years now. They are dreaming, and this Omar guy is an idiot. Act Syrian you idiot not American. You think Americans care about u!” John Smith's angry post from February 2015 reads "Zionist shill," probably a passionate misspelling for an offensive construction. Addressing Offendum directly, David Mastnak wrote the following comment in September 2015: "without Bashar, Syria would became Libya, who would rule? IS, FSA? lol what an ignorant moraas you are, read Noam Chomsky and educate yourself!' What these debates and dialogues indicate is that Offendum's goal of ending a global apathy against the Syrian war seems to be much more difficult than one would expect. Certainly, the commentators who use expletives in reference to him are far from apathetic. However, the anger one can easily read in their contributions represents a barrier against open dialogue. And so Offendum's project is certainly not even nearly close to being complete.

\section{NOTES}

a. Da'esh is also known as the Islamic State of Iraq and Syria (ISIS).

b. While many scholars have engaged in the hip-hop ethics debate from a variety of angles and stand-points such as Tricia Rose's 2008 book, The Hip Hop Wars: What We Talk About When We Talk About Hip Hop-And Why It Matters, New York: Basic/Civitas Books or Railand Rabaka's 2012 book Hip Hop's Amnesia: From Blues and the Black Women's Club Movement to Rap and the Hip Hop Movement, Lexington Books, we resort to Somers-Willet's perspective here because she writes of hip-hop's intersections with poetry. We believe that Offendum's hip-hop comes closest to poetry.

c. Mexicans and Syrians occupy two different immigration statuses that we want to acknowledge. While the first category contains mostly immigrant laborers, the latter is composed mostly of asylum seekers, refugees, and beneficiaries of a Temporary Protected Status (TPS).

d. For instance, Tunisian Hamada Ben Amor under the name of El General recorded "Rayes Le Bled," available on YouTube at https://www.youtube.com/watch?v=JupZw4SOwVQ\#action=share. Libyan rapper, Ibn Thabit, recorded the song "Benghazi II," which can be heard on YouTube as well, at https://www.youtube.com/watch?v=hFdTYSdAr A\#action=share. The Egyptian band Arabian Knightz recorded the song "Rebel" featuring Lauren Hill. The lyrics mix Arabic and English. This song is on YouTube at https://www.youtube.com/watch?v=Z696QHAbMIA\#action=share.

e. While it is impossible to know a YouTube respondent's ethnic origins considering solely their chosen screen name, we believe the names chosen to represent geographic disclosures of some sorts. This may not mean that a person identifies ethnically or nationally in a certain way, but it states their declared affinity to a certain cultural space. We have chosen to catalogue these respondents based on their declared affinity to the Middle East through linguistic transparency in "Middle Eastern" and "nonMiddle Eastern," although we are aware of the many complications that arise from this distinction.

\section{REFERENCES}

1. NPR Staff. (2011) The Arab Spring: A Year of Revolution. National Public Radio. http://www.npr.org/2011/12/17/143897126/the-arab-spring-a-year-of-revolution (accessed Aug 2016)

2. Staff. (2016) Syrian Civil War, in Encyclopadia Britannica. https://www.britannica.com/event/Syrian-Civil-War (accessed Aug 2016) 
3. The Syrian Refugee Crisis and Its Repercussions for the EU, Syrian Refugees, July 2016, http://syrianrefugees.eu/(accessed Aug 2016)

4. Turkish President Erdogan Appears in Istanbul to Denounce Army Coup Attempt, BBC News, 16 July 2016 , http://www.bbc.com/news/world-europe-36809083 (accessed Aug 2016)

5. Wehner, P. (2015) President Obama’s Hypocrisy on Syria, The New York Times, http://www.nytimes.com/2015/11/28/opinion/president-obamas-hypocrisy-on-syria.html? r=0 (accessed Aug 2016)

6. www.offendum.com (accessed Aug 2016)

7. Rawls, John, (2003) Justice as Fairness. A Restatement, 1; Harvard University Press, Cambridge, MA.

8. Versus: Hip Hop on Trial Debate, https://www.youtube.com/watch?v=r3-7Y0xG89Q (accessed Aug 2016)

9. Alridge, D. P. and Stewart, J. B., (2005) Introduction: Hip Hop in History: Past, Present, and Future, The Journal of African American History, 90. 3 The History of Hip Hop, 193.

10. Somers-Willet, S., (2009) The Cultural Politics of Slam: Race, Identity, and the Performance of Popular Verse in America, 70-72, 101, 104105, University of Michigan Press, Ann Arbor, MI.

11. Blanchard, B. The Social Significance of Rap \& Hip-Hop Culture, Ethics of Development in a Global Environment, Stanford University, https://web.stanford.edu/class/e297c/poverty prejudice/mediarace/socialsignificance.htm (accessed Aug 2016)

12. Williams, J. (2011) Historicizing the Breakbeat: Hip Hop's Origins and Authenticity, Song and Popular Culture 56, $137-139$.

13. Grow, K., Riot on the Set: How Public Enemy Crafted the Anthem "Fight the Power," in Rolling Stone http://www.rollingstone.com/music/news/riot-on-the-set-how-public-enemy-crafted-the-anthem-fight-the-power-20140630 (accessed Aug 2016)

14. Ramsaran, Dave and Simona J Hill, (2009) Hip Hop and Inequality: Searching for the "Real" Slim Shady, 25, Cambria Press, Amherst, New York.

15. Tate, G. Hip Hop: Music and Cultural Movement, in Britannica Online https://www.britannica.com/topic/hip-hop (accessed Aug 2016)

16. Bradley, Adam and Andrew DuBois eds (2010) NWA in The Anthology of Rap, 232, Yale University Press, New Haven, CT

17. Alex, Pate (2009) Defining Rap/Poetry, in African American Cultural Theory and Heritage : In the Heart of the Beat: The Poetry of Rap, 27, Scarecrow Press, Lanham, MD

18. Haupt, A., (2003) Hip-Hop, Gender and Agency in the Age of Empire, in Agenda: Empowering Women for Gender Equity, 57, Urban Culture, 22.

19. Simon, S. Hip Hop: Today’s Civil Rights Movement? NPR http://www.npr.org/templates/story/story.php? storyId=1178621 (accessed Aug 2016)

20. Reed, T. V., (2005) Art of Protest: Culture and Activism from the Civil Rights Movement to the Streets of Seattle, 14, University of Minnesota Press, Minneapolis, MN.

21. Lake, T., (2011) Cultural Resources, in The African American Lectionary, http:/ / www.theafricanamericanlectionary.org/culturalaids.asp (accessed July 2016)

22. Rabaka, Railand, (2012) Hip Hop's Amnesia: From Blues and the Black Women's Club Movement to Rap and the Hip Hop Movement, 217, Lexington Books, Lanham, MD.

23. Bynoe, Y., (2002) Getting Real about Global Hip Hop, Georgetown Journal of International Affairs 3.1, Special: 9/11: Facing A New Threat, 80-82.

24. Dinan, S. (2016). State Department Sets New Single-Day Record for Syrian Refugee Approvals, The Washington Times, http://www.washingtontimes.com/news/2016/may/24/state-department-sets-single-day-record-for-syrian/ (accessed Aug 2016)

25. Bayoumi, Moustafa, (2009) How Does It Feel to Be a Problem? Being Young and Arab in America, 3. Penguin Books, New York City, NY.

26. McCarthy and Jacobs, Muslim Databases and "Rabid Dogs": Trump, Carson and GOP in Explosion of Rhetoric over Syrians, The Guardian, https://www.theguardian.com/us-news/2015/nov/20/muslim-databases-and-rabid-dogs-gop-in-ugly-scrambleto-vilify-syrian-refugees (accessed July 2016)

27. Lithwick, D. and Reiman Henneman, L., Refugee-Fearing Mayor Wants to Round Them Up, Slate http://www.slate.com/articles/news_and_politics/jurisprudence/2015/11/roanoke_mayor_on_refugees_and_japanese_inter nment_camps.html (accessed July 2016)

28. Safieh, R., (2013) Identity, Diaspora, and Resistance in Palestinian Hip-Hop, in Palestinian Music and Song: Expression and Resistance Since 1900 (Kanaaneh, M., Thorsen, S. M., Bursheh, H., McDonald, D. A. Eds) 69-72, Indiana University Press, Bloomington.

29. n.a. Halal Hip Hop, Beliefnet, http://www.beliefnet.com/entertainment/music/2006/04/halal-hip-hop.aspx (accessed July 2016)

30. Peek, Lori, (2010) Behind the Backlash: Muslim Americans after 9/11, 5. Temple University Press, Philadelphia, PA. 
31. Lichtblau, E. (2015) Crimes Against Muslim Americans and Mosques Rise Sharply, in The New York Times, http://www.nytimes.com/2015/12/18/us/politics/crimes-against-muslim-americans-and-mosques-rise-sharply.html?_r=0 (access July 2016)

32. Davy, S. For Hip-hop Artist Omar Offendum, Apathy toward Syria Is Not an Option, Public Radio International, http://www.pri.org/stories/2015-05-04/hip-hop-artist-omar-offendum-apathy-toward-syria-not-option (accessed July 2016)

33. Style, A. MOCAfest 2015: Omar Offendum Preaches Love and Justice with Hip-Hop, Aquila-style.com. http://www.aquilastyle.com/wief-marketplace-of-creative-arts/performance-arts/mocafest-2015-omar-offendum-preaches-love-and-justicewith-hip-hop/106280/ (accessed July 2016)

34. Rhythms, Rebels, and Resistance: Omar Offendum on Youth Politics in the Middle East, Sydney Ideas, http://sydney.edu.au/sydney ideas/lectures/2015/omar offendum.shtml (accessed July 2016)

35. Iandoli, K., (2012) Beats, Rhymes, and Death, Vice Media, http://www.vice.com/en ca/read/beats-rhymes-and-death0000345-v19n11 (access July 2016)

36. N.a (2002) Topographic Map of Syria, in Nations Online http://www.nationsonline.org/oneworld/map/syria-topographicmap.htm (accessed July 2016)

37. Mark, J. Joshua. Hammurabi, in Ancient History Encyclopedia, http://www.ancient.eu/hammurabi/ (accessed December 2016)

38. Dawishe, Adeed, (2016) Arab Nationalism in the Twentieth Century: From Triumph to Despair, 2-3, 125. Princeton University Press, Princeton, NJ.

39. Il-Khanid Dynasty in The Encyclopedia Britannica, https://www.britannica.com/topic/Il-Khanid-dynasty (accessed December 2016)

40. Shamoun, Sam, Abraham and the Child of Sacrifice: Isaac or Ishmael? in Answering-Islam.org, http://www.answeringislam.org/Shamoun/sacrifice.htm (accessed December 2016)

41. Gualtieri, Sarah (2009) Claiming Whiteness: Syrians and Naturalization Law in Between Arab and White: Race and Ethnicity in the Early Syrian American Diaspora, University of California Press, Oakland, CA

42. A Community of Many Worlds: Arab Americans in New York City, in Allied Media Corp. http://www.allied-media.com/ArabAmerican/NY-Arabs.htm (accessed December 2016)

43. The Moor Next Door, Smile, in The Moor Next Door Wordpress, https://themoornextdoor.wordpress.com/2011/08/09/6837/ (access July 2016)

44. Said, Edward, (1978) Orientalism, 4-15, Routledge, London, UK.

45. Kipling, Rudyard. The White Man's Burden, in Reading About the World: A Reader for the Study of World Civilizations, Washington State University, https://public.wsu.edu/ brians/world civ/worldcivreader/world civ reader 2/kipling.html (accessed December 2016)

46. Oakley, C., US Imperialism and the War for the Middle East, in Marxist Left Review, http://marxistleftreview.org/index.php/no8-winter-2015/118-us-imperialism-and-the-war-for-the-middle-east (accessed July 2016)

47. Woodward, D. The Middle East during World War I, in BBC History, http://www.bbc.co.uk/history/worldwars/wwone/middle east 01.shtml (accessed July 2016)

48. Jwaideh, W. Ash-Sharif al-Idrisi, Arab Geographer, in Encyclopedia Britannica, https://www.britannica.com/biogra phy/alSharif-al-Idrisi (accessed July 2016)

49. Reynolds, Gabriel (2004) A Muslim Theologian in the Sectarian Milieu: Abd al-Jabbar and the Critique of Christian Origins, 68, Brill, Leiden, Netherlands.

50. Goody, Jack, (2010). Rebirth in Islam in Renaissances: The One or the Many? 94-145, Cambridge University Press, Cambridge, UK.

51. Yule, Henry, A. C., (2013) Burnell Hobson-Jobson: The Definitive Glossary of British India, Oxford University Press, Oxford, UK.

52. Pirbhai, Mariam, (2009) Mythologies of Migration, Vocabularies of Indenture: Novels of the South Asian Diaspora in Africa, the Caribbean, and Asia-Pacific, $1^{\text {st }}$ edition, 108, University of Toronto Press, Toronto, Canada.

53. Freire, P. (2000) Pedagogy of the Oppressed, $30^{\text {th }}$ Anniversary Edition, Bloomsbury Academic.

54. Hokayem, Emile (2013) Syria's Uprising and the Fracturing of the Levant, 153, The International Institute for Strategic Studies, London, UK

55. Zachs, Fruma, and Sharon Halevi, (2015) Gendering Culture in Greater Syria: Intellectuals and Ideology in the Late Ottoman Period, 8 , I.B. Tauris, New York City, NY.

56. Tekdal Fildis, Ayse, (2011) The Troubles in Syria Spawned by French Divide and Rule, Middle East Policy Council, 8.4, http://www.mepc.org/journal/middle-east-policy-archives/troubles-syria-spawned-french-divide-and-rule (accessed December 2016)

57. Zonszein, M. Walled off: 12 Years of Israel's Separation Barrier, in Aljazeera, http:/ / america.aljazeera.com/articles/2014/3/12/visual-activism-activestillsphotographsthebarrierwall.html (accessed July 2016)

58. Natan, Y. (2006) Moon-o-theism. Volume II. Create Space, 411. 
59. Watson Institute, (2015) Costs of War, Brown University, http://watson.brown.edu/costsofwar/costs/human/civilians/iraqi (accessed December 2016)

60. Sami Matar, Samimatar.com, http://samimatar.com/ (accessed December 2016)

61. Faham, Amr, "Comments to Omar Offendum's \#SYRIA," Youtube, 2015, https://www.youtube.com/watch?v=TXjEWrhkb6g\&lc=z13fzdf45pzyyxkdw232tphagyanhzysb (accessed December 2016)

62. Offendum, Omar, “\#SYRIA,” Offendum Blogspot, 2012, http://offendum.blogspot.com/2012/03/syria.html (accessed December 2016)

63. Associate Press, (2011) Syrian Uprising Song Writer Meets Gruesome End, CBS News. http://www.cbsnews.com/news/syrian-uprising-songwriter-meets-gruesome-end/ (accessed July 2016)

64. The Desmond Tutu Peace Foundation Exhibitions, The Desmond Tutu Peace Foundation. http://www.tutufoundationusa.org/exhibitions.html (accessed July 2016)

65. Offendum, Omar, USA. Pdx.edu. Portland State University, http://www.pdx.edu/middle-east-studies/event/art-andnonviolent-resistance-syria-featuring-hip-hop-artist-omar-offendum?delta $=0$ (accessed July 2016)

66. Fleming, E. (2011) Hot, Loud, Angry and Political for Justice, Salem-news.com, http:/ /www.salemnews.com/articles/february282011/political-jutice-ef.php (accessed July 2016)

67. qtd. in Davy, S. For Hip-hop Artist Omar Offendum, Apathy toward Syria Is Not an Option, Public Radio International, http://www.pri.org/stories/2015-05-04/hip-hop-artist-omar-offendum-apathy-toward-syria-not-option (accessed July 2016)

\section{ABOUT THE STUDENT AUTHORS}

Harry Olafsen is currently pursuing a Bachelor of Arts in History and English at Saint Francis University in Loretto, Pennsylvania. His emphasis on the plight of Syrian refugees and social responsibility has emerged from multiple research assignments about the Middle East and Islam, particularly with a focus on women's rights. His other work focuses on women's diaries (mainly housewives) from the American Civil War and how each woman's personal experience helped to perpetuate the war effort.

Mohammed Ali is pursuing a Bachelor's degree at Indiana University of Pennsylvania hoping to become a physician. His work on the Syrian crisis first began with a public presentation on the health issues children of Syrian refugees' encounter. His interest in social justice drives him to become engaged in local equity issues and thus a responsible citizen.

Mikayla McCord is currently pursuing a Bachelor of Business in International Business and Economics degree with a focus in Portuguese and Spanish at the University of South Carolina in Columbia, South Carolina. Her work on empowerment through music in this research project stemmed from both an interest in international affairs and social justice. Some of her other work has included research on the history of the conflict between Palestinians and Israelis.

\section{PRESS SUMMARY}

In this paper, we argue that Syrian-American educator, performer, poet, and musician Omar Offendum transforms his hip-hop music into an effective tool of political propaganda that can raise social consciousness to the needs of Syrians today and harbor social justice for Syria. Employing both English and Arabic, Offendum performs the authenticity of his hybrid identity and linguistically outlines a cultural space for a diverse audience to come together. Offendum does so because he feels the obligation and responsibility to fight for the rights of the often stereotyped and oppressed Middle Eastern individuals in both the East and the West, in order for all people to unite in the spirit of resistance and solidarity with one another. 